\title{
7 HE INFLUENCE OF EUROPEAN UNION OUTER POLICY INITIATIVES TO THE \\ 1 EU-RUSSIA RELATIONS: CASES OF NORTHERN DIMENSION AND BLACK SEA SYNERGY
}

\section{Giedrius Kviklys}

Vytautas Magnus University, E-mail: g.kviklys@gmail.com

\section{Acknowledgments}

This paper has been presented at the Fourth International Conference on Nordic and Baltic Studies „Empire-building and Region-building in the Baltic, North and Black Sea Areas”, in Constanta, Romania, May 24-26, 2013.

\begin{abstract}
:
This article discusses how Russia treats two foreign region initiatives of EU Northern Dimension and Black Sea Synergy and how it responds to the EURussia bilateral relations. These two initiatives have been chosen because both of them directly border Russia and both concern Kremlin's foreign policy. The problem arises from the fact that European Union sees its outer policy as a tool for development of cooperation and prosperity, whereas Russia wants to dominate or has a right to influence all the processes which are going on at its borders and Kremlin does not want any other huge player appear at its borders. Consequently, such a situation directly influences the bilateral relations between EU and Russia.
\end{abstract}

\section{Rezumat:}

Acest articol ia în discuție modul în care Rusia tratează două inițiative de politică externă ale UE de la granițele sale: Dimensiunea Nordică şi programul Black Sea Synergy, şi modul în care acestea afectează relațiile bilaterale dintre UE şi Rusia. Aceste două inițiative de politică externă au fost alese deoarece ambele se desfăşoară la granița cu Rusia şi ambele ating politica externă a Kremlinului. Problema apare datorită faptului că UE vede politica sa externă ca o unealtă de cooperare şi prosperitate, în timp ce Rusia doreşte să domine şi să influențeze toate procesele care se petrec la granițiele sale, Kremlinul nedorind să întâlnească vreun al actor major la frontierele sale. Aşadar, situația de față influențează relațiile bilaterale dintre UE şi Rusia.

Keywords: EU, Russia, relations, Black Sea Synergy, Northern Dimension 


\section{Introduction}

The European Neighbourhood Policy (ENP) was developed in 2004, with the objective of avoiding the emergence of new dividing lines between the enlarged EU and its neighbours and instead strengthening the prosperity, stability and security of all. It is based on the values of democracy, rule of law and respect of human rights, accompanied by inclusive economic development. The Lisbon Treaty commits the EU to the "development of a special relationship with neighboring countries aiming to establish an area of prosperity and good neighborliness, founded on the values of the Union and characterized by close and peaceful relations based on cooperation". For that purpose "the EU may conclude specific agreements with the countries concerned"1. Usually such cooperation is implemented in the frame of bilateral or regional partnership (Northern Dimension, the Eastern Partnership, the Union for the Mediterranean and the Black Sea Synergy). Quite an important role in this context is played by Russia, because this country is the largest neighbor of the EU and three European Union foreign policy initiatives - Northern Dimension (ND), the Eastern Partnership (EP) and the Black Sea Synergy (BSS) - directly border Russia. Therefore, first-hand relations between Russia and the EU have become inevitable.

In such a case the problem arises due to the fact that the European Union sees its foreign policy as a tool for development of cooperation and prosperity, whereas Russia has so far demonstrated that it aims to dominate or influence all the processes in the neigbouring regions. At the same time such a situation presupposes the aim of this paper: to consider Russia's attitudes towards Northern dimension and Black Sea Synergy. This paper discusses about how Russia treats EU's foreign region initiatives - Northern dimension and Black Sea Synergy and how this policy responds to bilateral EU-Russian relations. Especially bearing in mind the fact that Russia's new official foreign policy only states that "Russia will support further spread of Northern Dimension, as a regional cooperation platform,

\footnotetext{
1European Neighbourhood Policy. European Commission, http:/ / ec.europa.eu/world/enp/welcome_en.htm, accessed at 14.03.2013 184
} 
and it's project potential"2, but does not give any concrete steps of implementation.

\section{The Northern Dimension and Russia's position towards it}

The creation and ratification of Northern Dimension (further ND) in 1997 received lot of enthusiasm from politicians and scientists, including the Russian side. As Bolotnikova and Mezhevich noted, everybody emphasized that ND will become a cornerstone for the changes of EU relations with its neighboring countries and the ND will become an example of cooperation ${ }^{3}$. Russians treated this policy quite positively, because together with other European countries the EU was going to prepare a common regional policy towards Russia's North-west (which is strategically important according to its economical and social parameters of theas compared to the whole country). ${ }^{4}$ But the actual actions were different from the aims which had been declared.

As Bolotnikova and Mezhevich mentioned, the initial joy regarding the opportunities which ND supposedly was to deliver was too optimistic. Everybody spoke about various opportunities, but actual steps were showing different outcomes - there were no resulting opportunities to be seen, which everybody had expected: the program was not fully institutionalized, there was no consistent working management structure; EU did not give any additional financial support; main action plans were only pointed to the extraction of natural resources in Russia's North-west region; all decisions were taken by one side - the EU, without consultations with other countries. ${ }^{5}$ Russia was unhappy with this, so it's participation in the ND has become more nominal than real.

\footnotetext{
${ }^{2}$ КониепииявнешнейполитикиРоссийскойФедерации, 4 dalis, 65 straipsnis. УтвержденаПрезидентомРоссийскойФедерацииВ.В.Путиным 12 февраля 2013 г. МинистерствоиностранныхделРоссийскойФедерацией. 2013,http:/ / www.mid.ru/brp_4.nsf/newsline/6D84DDEDEDBF7DA644257B160051BF7F,a ccessed at 14.03.2013

ЗБолотникова, Е.Г., "Северногоизмерения":современноесостояниеиперспективыразвития".

„Балтийскийрегион“, $\quad$ №4 115-126, http://journals.kantiana.ru/upload/iblock/e41/hdnkiyiaestquimaettgja,\%20gwxgxxjtvqwi bf.pdf, accessed at 13.02.2012

4Глинкина, Е. А. "Северноеизмерение" какполитикаЕвропейскогоСоюза: правовойаспект". "Российскоеправовинтернете", No 2 (2011): http:/ / www.rpi.msal.ru/prints/201102glinkina.html, accessed at 13.02.2012 
At the same time, as A. Izotov says, Russia still does not have a complex view on ND andemphasizes bilateral relations with specific countries (for example, some issues related to the region are solved with Germany or Poland or other countries which are around the Baltic sea: Scandinavian countries, the Baltic states etc. $)^{6}$ Thus it is shown that Russia prefers to cooperate in smaller scale, where the weight of her voice becomes stronger and is easier to enact a decision when comparing to whole of ND, where, as E. Belokurova says, Russia has to negotiate with 8 EU members, Norway and Iceland, which usually support EU position, and Russia is left out on its own. ${ }^{7}$

The other reason for Russia's negative position towards ND and whole EU was that according to the Amsterdam agreement, which was signed in 1999 (one of the first tries to frame a Common Security and Defense policy of the EU), EU sought the entrenchment of democracy and market economy in Russia, which could help influence all the political processes in this country and would guarantee it's openness and predictability. But this goal of Western Europe was not implemented, because after V. Putin became the President of Russia the resistance to such EU policy began and Russia, by contradistinguishing "old“ and "new“ EU members tried to change the situation into one more positive for Russia's interests. The result of such policy - The Partnership and Cooperation Agreement between Russia and EU was not signed in 2007 because it was vetoed by Poland and the European Commission supported the Polish position. It was the proof that these two sides, when the talks reached "high policy", cannot come to any decision". Therefore the implementation of ND confronted with difficulties, which had to be solved.

When such a situation arose, the representatives of Finland's Ministry of Foreign Affairs appealed to Russian colleagues with an aim to renew the Northern Dimension and the cooperation in the frame of this initiative. The result of this dialogue, a renewed ND, was presented in 2006. There were few changes: the principle of equality was consolidated; the

\footnotetext{
'Information according an interview with Изотов,А. В. The interview is done by Giedrius Kviklys, in Saint Petersburg (Russia), 06.12.2012

7Information according an interview with Belokurova, E. The interview is done by Giedrius Kviklys, in Saint Petersburg (Russia), 04.12.2012

8Бусыгина, И. М., Филипов, М. Г. "Северноеизмерение": стретгииучастников". „Балтийскийрегион", №1 (2009) p. 5563,http://journals.kantiana.ru/baltic_region/327/884/,accessed at: 13.02.2012 186
} 
question of financing was framed; a programme management structure was created; the ND becomes a place where Russia and EU are implementing their regional policy. ${ }^{9}$ There were enough such changes that Russia could start its work in this initiative and the principle of equality became unique because countries which are not EU members may influence the politics of the initiative. Such openness made the trust between countries stronger and encouraged the further development of the ND. The results of this process are seen from the fact that there were partnerships created in transport, logistics and cultural areas, and science institutes were established among other things.

Another positive step in the development of ND is that there are no "high policy“ questions, which would be related to oil, gas, military security and which are important to a country as a whole, but the focus is on the projects and questions which are important to the particular region only. Though, questions about nuclear security and energy reduction were included in the negotiation schedule, but they were covered by and grouped with environmental issues, so, further negative discussions were avoided. ${ }^{10}$ More, Russia even benefited from it: if at the end of XXth century Russia was the main source pollution in the Baltic Sea, after the implementation of ND environmental policy, Poland became the main source of pollution. ${ }^{11}$

However, despite the fact that there are positive changes in the ND initiative, like improved cooperation between countries, Russia has evolved from being the object of EU neighborhood policy to a subject of it and now is able to pursue pragmatic politics, but there are a few problematic aspects to this initiative: there are no exact rules how the funds from European neighborhood and partnership instrument should be used; high level politicians do not look very interested in the Northern Dimension anymore, for example, there was no ND question on the agenda during the official meeting of the presidents of Finland and Russia; the geographical scope of ND has expanded and now it covers Barents/Euro-Arctic region, which raises an amount of problematic issues. Because of such changes it

\footnotetext{
9'Болотникова, Е.Г., Межевич, Н.М., 2010, 115-126

10Бусыгина, И. М., Филипов, М. Г., 2009., 55-63

${ }^{11}$ Худолей, К.К., Ланко, Д. А "Санкт-ПетербургвБалтийскомРегионе". "Балтийскийрегион", $\quad$ №1(1) 6476,http://journals.kantiana.ru/baltic_region/327/885/, accessed at: 13.02.2012
} 
becomes much more difficult to administer the ND and the program has changed its initial principles. ${ }^{12}$ As K. Khudolej adds, the agenda of the ND is getting closer to the 4 common spaces of EU-Russia cooperation ${ }^{13}$ and such a process is really harmful to the initiative because if its activity will be based on these 4 common spaces, it might create stagnation of all the processes and the program might stop functioning. ${ }^{14}$ Furthermore, the economical crisis forced countries to concentrate on their internal finances, so, as N. Mezhevich says, it brought about the "economical death of the project" $^{\prime \prime} .15$

Generally speaking, it is said about the Northern Dimension that even if there arise questions regarding the further development and implementation of this Finnish initiative, because the process is not as fast as everybody expected when the ND was created, but at the same time everybody agrees that it has more positive than negative aspects. In this way, the ND is seen as an instrument which can encourage the unification of EU and the rest of Europe, at the same time leaving a chance to secure the individuality and particularity which are typical to this northern region. ${ }^{16}$ At the same time it should be said that Russia regards another EU initiative - the Black Sea Synergy - absolutely differently.

\section{The Black Sea Synergy and Russia's position towards it}

When Romania and Bulgarian became EU members in 2007, European Union borders reached the Black Sea. A special policy towards this region was needed. The EU had two options: it could join already existing structures, like the Organization of Black Sea Economic Cooperation (further BSEC), or create something new. In this case the second option was chosen and in 2007 Brussels created its own foreign policy initiative titled: Black Sea Synergy (further BSS). This initiative

\footnotetext{
12Болотникова, Е.Г., Межевич, Н.М., 2010, 115-126

13 Since 2003 EU-Russia cooperation is defined according 4 common spaces (The Common Economic Space; The Common Space of Freedom, Security and Justice; The Common Space of External Security; The Common Space of Research and Education, Including cultural aspects), http://www.urm.gov.lt/index.php?2129033515, accessed at: 13.02.2013

${ }^{14}$ Information according an interview with Khudolej, K. K.. The interview is done by Giedrius Kviklys, in Saint Petersburg (Russia), 06.12.2012

15Information according an interview with Mezhevich, N. M.. The interview is done by Giedrius Kviklys, in Saint Petersburg (Russia), 06.12.2012

16Дерябин, Ю. "Северное измерение" и интересы России". "СовременнаяЕвропа" No.2, (2000), http://www.ieras.ru/journal/journal2.2000/6.htm, accessed at: 13.02.2012 188
} 
covers all the countries around the Black Sea, including Moldova, Azerbaijan, Armenia and Greece. The main areas of cooperation are: democracy and human rights; environment; fishery; energy policy; scientific cooperation; peaceful resolution of conflicts, etc. ${ }^{17}$ Basically, all these principles should be implemented according to the EU regulations. At the same time it should be mentioned that the EU also achieved an observer status at BSEC, but its BSS provoked a negative reaction from Russia and Turkey, because the EU refused to join the already existing governmental structures and to accept the already established rules in the region.

One of the first attempts to make the BSEC and EU members cooperate in the Black Sea region was initiated in 2008, in Kiev, where there was a special session of ministers of BSEC. During this session, a question of possible cooperation in the region was negotiated and a common declaration about it was signed. However, the Russian side, led by the first deputy minister for foreign affairs A. Denisov, did not veto the declaration, but expressed Russia's position that it would accept the cooperation between BSEC and EU when the EU will treat them as an equal partners and will not start dictating its conditions or breaking the established status quo, excluding Russia and Turkey - the most important countries in the Black Sea region. ${ }^{18}$ Russia suggested that a better way for the EU would be to join BSEC instead of further developing BSS. This principle is confirmed by T. Romanova (assoc.prof. at the SPSU Department of European Studies), who says that the BSS is useful to the EU, but from the Russian point of view it is useless, because it changes the status quo in the region to benefit the new player. A better approach for Russia would be if the EU joins BSEC and sticks to the rules of this organization because that would help secure power balance and equality between Russia, Turkey and the EU.19

\footnotetext{
17KomisijosKomunikatasTarybaiirEuroposParlamentui "JuodosiosJūrossinergija _ naujaregioniniobendradarbiavimoiniciatyva“. EuroposBedrijųKomisija, Briuselis, 2007.04.11. Rasta:

http://eurlex.europa.eu/LexUriServ/LexUriServ.do?uri=COM:2007:0160:FIN:LT:PDF, accessed at: 18.05.2013

18Краснов, Д. В. "Россия, ТуриияиЕвропейскийсоюзвборьбезавлияниеврегионеЧерногоморя". Сборникматериалов.Третийвсероссийскиймусульманскийфорум, 2009.01.13, http://www.idmedina.ru/books/materials/rmforum/3/umma_krasnov.htm, accessed at 17.05.2013

${ }^{19}$ Information according an interview with Romanova, T. A.. The interview is done by Giedrius Kviklys, in Saint Petersburg (Russia), 06.12.2012
} 
In Russia, the Black Sea Synergy is treated as an initiative which seeks to reduce the influence of this country in the region and in the whole of Europe, especially, when we speak about energy resources and their transportation to Europe bypassing Russia. Such policy automatically creates confrontation, increases competition between countries and it is suggested that such actions might increase the influence of Romania and Bulgaria in the region. ${ }^{20}$ As an example, Romania and Bulgaria participate in the AGRI Project (Azerbaijan - Georgia - Romania Interconnector, see Figure No.1), where liquefied natural gas is transported from Azerbaijan to Europe through Georgia (Kulevi) and Romania (Constantsa). There are other projects such as the Baku-Tbilisi-Ceychan oil pipeline or Baku-TbilisiErzurum gas pipeline (see Figure No.2) ${ }^{21}$. Such policy is treated as a threat to the internal and foreign policy of Russia and as an aim to reduce Russia's influence and undermine its interests in region.

Figure 1, Project AGRI

\section{PROPOSED AZERBAIJAN-GEORGIA-ROMANIA- INTERCONNECTOR (AGRI)}

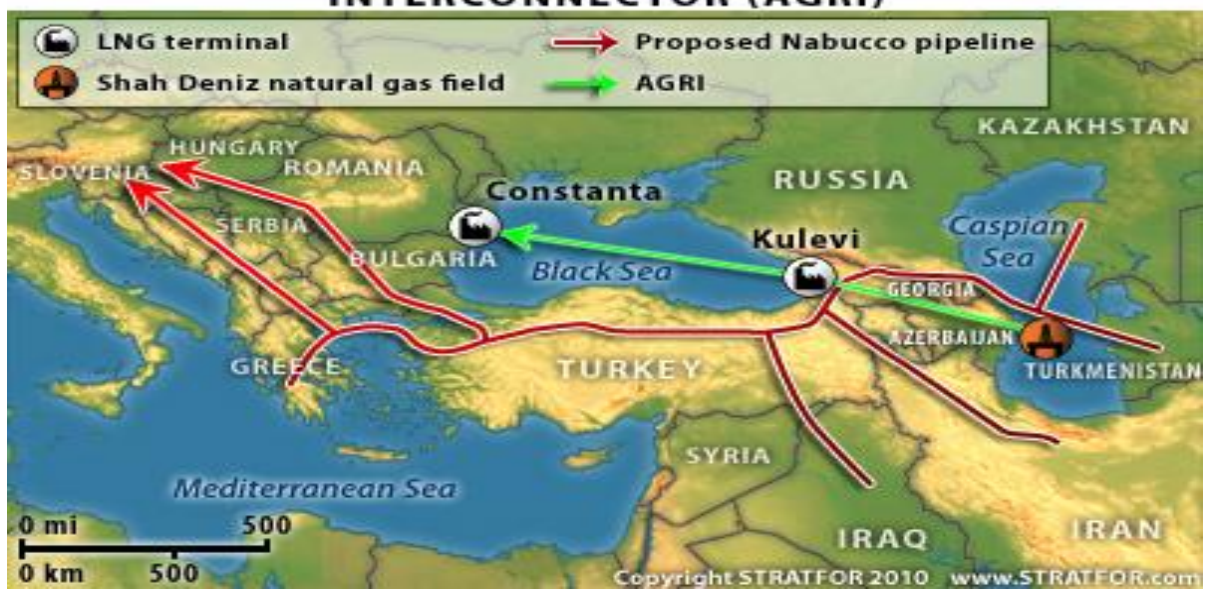

20Косов Ю.В., Торопыгин А.В. „Развитие Европейской региональной политики: путь к углублению сотрудничество или к конфликту?“. "Политэкс", No.2 (2009), http://www.politex.info/content/view/577/, accessed at 17.05.2013

21Жильцов, С. „ЕСрасширяетчерноморскиеинициативы“. Дипкурьер, 2011.06.27, http://www.ng.ru/courier/2011-06-27/9_es.html, accessed at: 17.05.2013 
Source: Natural Gas Europe, http:// www.naturalgaseurope.com/agri-lng-invites-bids-for-feasibilitystudy-3874, accessed at: 22.05.2013

Figure 2, the Baku-Tbilisi-Ceychan oil pipeline and Baku-TbilisiErzurum gas pipeline

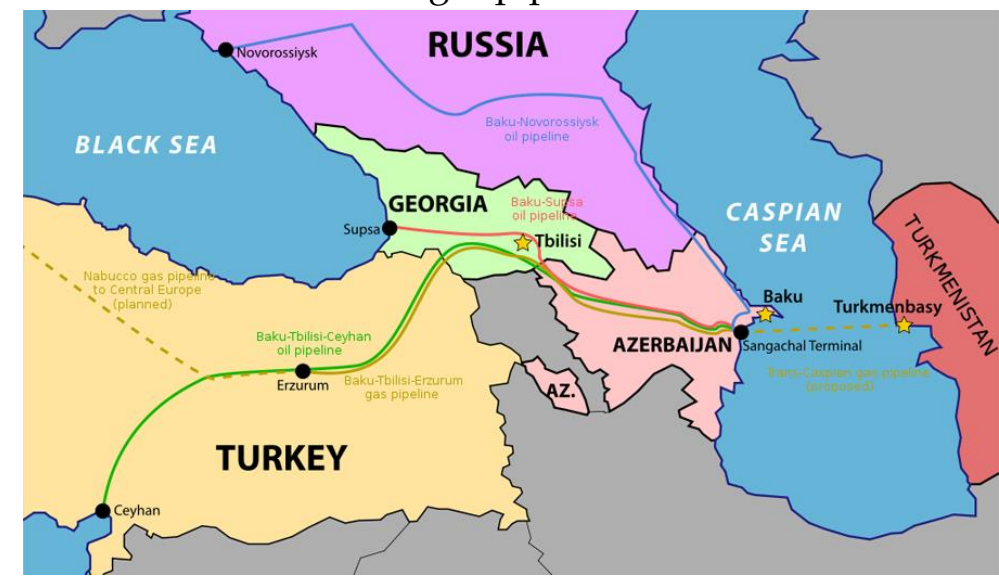

Source:

Black

Sea

News,http://www.blackseanews.net/en/read/54763, accessed at: 22.05.2013

Also, Russian experts underline that regional initiatives of the EU, such as the ND, BSS or the EP, do not represent the interest of EU as a whole, but are a concentrated expression of private interests of specific EU members, for example, the ND - Finnish interest, the BSS - Romania and Bulgaria, and the vitality of these initiatives depends on ambitions, political actions and willingness to do something by the initiators. ${ }^{22}$ In this way, all EU regional initiatives are directly related to the expansion of the organization, because new members seek to secure their own strong specific foreign policy, trying to somehow distinguish themselves in a common foreign policy of EU and feel quite important when questions related to their interests, are pending. ${ }^{23}$

22Агаджанян, М."Программа "Черноморскаясинергия" иЮжныйКавказ". ФондНараванк, 2010.01.11, $\quad$ http://www.noravank.am/rus/issues/detail.php?ELEMENT_ID=4262, accessed at: 17.05.2013

23Interview withRomanova, T. A., 2012 
Nevertheless, debates focus on the negative aspects, but one positive aspect is discernible at the same time, though it depends on the point of view. The BS region is treated as very heterogenic, while there are many so called "frozen conflicts" on hold both inside the countries and between countries, for example: South Ossetia and Abkhazia in Georgia, since 2008 when acknowledged as independent states by Russia, or conflict between Armenia and Azerbaijan because of the Nagorno Karabakh, etc. This is why it is difficult to make this region peaceful and secure. Russia works here by using the principles of bilateral agreements and "hard power", while the EU is working by using the principles of "soft power". ${ }^{24}$ It is mentioned that, first of all, EU's activities are focused on the spreading of democratic norms and ideas, creates public institutions and at the same time trying to start dialogues between different governments and ordinary people, which could help solve the "frozen conflicts". Such policy is expressed in the words of J. M. Barosso, who stated that prosperity and stability in XXI century will bring economic benefit and dialogue, not rockets and demonstrations of power. The role of Russia becomes ambivalent in this case: from one point of view it looks like Russia is pulled back from resolving the conflict, as people prefer EU suggested cooperation conditions more than Russia's, but from another point of view there is a chance given to Russia, which still has a huge influence in Caucasus, to find and suggest its own version of cooperation policy in the region. ${ }^{25}$

In this a case the BSS is treated differently: on the one hand it looks like an opportunity for Russia to renew its policy in the region, but, on the other hand, BSS is treated as yet another institution of the "bureaucratic machine", which is more important to Romania and Bulgaria than to the European Union as a whole, due to the fact that Romania and Bulgaria wanted to somehow gain attention for themselves in the EU. In addition, this idea is supported by the fact that until 2007 the EU didn't participate in any processes in the region. Furthermore, this BSS project looks absolutely useless to Russia because there is the BSEC, where Russia together with Turkey play the main role and the EU joining it would make the BSEC

\footnotetext{
24Interview withИзотов,А. В., 2012

25Яшина, А. „Кто обеспечит развитие и безопасность Черного Моря?“. "УкраинаРоссия. Второе дыхание", №3 (2010),http://www.ia-centr.ru/expert/9735/, accessed at 17.05.2013
} 
stronger, so, there was no need to create any new institution, which does not work - there is only one report on the implementation of BSS and which was presented in 2008. It shows that this initiative does not look very interesting to Brussels, but makes it more difficult to develop positive EURussian relations because of its uncertainty and possible use in the future.

\section{Conclusion}

In conclusion, it might be said that the ND is treated as an initiative, which stimulates cooperation between the EU and Russia, though there are some difficulties, but Russian outlook is quite positive and sees this foreign region initiative more beneficial than negative and agrees that the ND might help both sides cooperate closer. But the situation is absolutely different with the other foreign policy initiative under discussion, where Russia views the BSS negatively, because this initiative does not look viable and Russians do not care a lot about it at the moment, but nobody knows how the BSS might be used in the future and, at this point, it is seen more as a danger to Russia's interests in the region and its cooperation with the EU. Therefore, the BSS becomes a rather negative aspect to EU-Russian relations.

\section{References}

\section{Interviews:}

Interview with Изотов,A. В., which is done by Giedrius Kviklys, in Saint Petersburg (Russia), 06.12.2012

Interview with Belokurova, E., which is done by Giedrius Kviklys, in Saint Petersburg (Russia), 04.12.2012

Interview with Khudolej, K. K.., which is done by Giedrius Kviklys, in Saint Petersburg (Russia), 06.12.2012

Interview with Romanova, T. A., which is done by Giedrius Kviklys, in Saint Petersburg (Russia), 06.12.2012

Interview with Mezhevich, N. M., which is done by GiedriusKviklys, in Saint Petersburg (Russia), 06.12.20124

\section{Chapters in Volumes}

Болотникова, Е.Г., Межевич, Н.M. "Политика "Северногоизмерения":современноесостояние и 
перспективыразвития". „Балтийскийрегион“, №4(6), Издательства БФУ им. И. Канта, 2010, 115-126
Глинкина,
E.
A.
"Северноеизмерение" какполитикаЕвропейскогоСоюза: правовойаспект". "Российскоеправо $b$ интернете", No 2, 2011.

Бусыгина, И. М.,Филипов, М. Г. "Северноеизмерение": стретгииучастников". „Балтийскийрегион“, №1(1), Издательства БФУ им. И. Канта, 2009, 55-63

Худолей, К.К., Ланко, Д. А "Санкт-Петербург в БалтийскомРегионе". „Балтийскийрегион“, №1(1), Издательства БФУ им. И. Канта, 2009, 64-76

Дерябин, Ю. "Северноеизмерение" и интересыРоссии". “СовременнаяЕвропа" No.2, ИнститутЕвропы PAH, Maskva, 2000.
Косов
Ю.В.,
Торопыгин
A.B.

„РазвитиеЕвропейскойрегиональнойполитики:

путь

$\mathrm{K}$ углублениюсотрудничествоили к конфликту?“. „Политэкс" , No.2, 2009

Яшина,

A.

„Ктообеспечитразвитие

и безопасностьЧерногоМоря?". "Украина-Россия. Второе дыхание", №3/2010

\section{Official documents}

КонцепциявнешнейполитикиРоссийскойФедерации, 4 dalis, 65 straipsnis.

УтвержденаПрезидентомРоссийскойФедерацииВ.В.Путиным

февраля 2013

$\Gamma$.

МинистерствоиностранныхделРоссийскойФедерацией. Nr. 303-18-022013

KomisijosKomunikatasTarybaiirEuroposParlamentui

"JuodosiosJūrossinergija - naujaregioniniobendradarbiavimoiniciatyva“. EuroposBedrijųKomisija, Briuselis, 2007.04.11, http://eurlex.europa.eu/LexUriServ/LexUriServ.do?uri=COM:2007:0160:FIN:LT:PD F, accessed at: 2013.05.18

\section{Websites of Official institutions}

European Neighbourhood Policy. European Commission, http:/ / ec.europa.eu/world/enp/welcome_en.htm, accessed at: 14.03.2013 


\section{Web postings}

Краснов, Д. В. "Россия, Туриия и Европейскийсоюз $b$ борьбезавлияние b регионеЧерногоморя". Сборникматериалов.Третийвсероссийскиймусульманскийфорум, 2009.01.13.

http://www.idmedina.ru/books/materials/rmforum/3/umma_krasnov. $\underline{\mathrm{htm}}$, accessed at: 17.05.2013

Жильцов, С. „ЕС расширяетчерноморскиеинициативы“. Дипкурьер, 2011.06.27, http://www.ng.ru/courier/2011-06-27/9_es.html, accessed at: 17.05.2013

Агаджанян, М."Программа "Черноморскаясинергия" и ЮжныйКавказ“. ФондНараванк, 2010.01.11, http://www.noravank.am/rus/issues/detail.php?ELEMENT_ID=4262, accessed at: 17.05.2013 